\title{
KYAI HAJI AHMAD SANUSI (1888-1950): KARYA-KARYA DAN PEMIKIRAN ULAMA SUKABUMI
}

\author{
Anwar $^{1}$, Maslani ${ }^{2, *}$, Ratu Suntiah ${ }^{3, *}$ \\ ${ }^{1}$ Mahasiswa Pascasarjana, UIN Sunan Gunung Djati Bandung, JL. A.H. Nasution 105 \\ Bandung \\ ${ }^{2,3}$ Jurusan Pendidikan Agama Islam, UIN Sunan Gunung Djati Bandung, \\ JL. A.H. Nasution 105 Bandung \\ ratusuntiah@uinsgd.ac.id
}

\begin{abstract}
This paper present the work and thoughts of a scholar from Sukabumi, West Java. Namely Kyai Haji Ahmad Sanusi (KHAS) with particular focus on one of his works in the field of Islamic Tasawwuf. In addition to his reputation as an outstanding scholar in 18th century, Kyai Haji Ahmad Sanusi (KHAS) is also famous as Islamic thinker and wraiter who are very productive in religious works. Even including one of the influential figures in the archive of the registration of Indonesian and the leading one in Java in 1942. This research is based on bibliographic data. This study found that KH. Ahmad Sanusi (KHAS) is one of the productive clerics in writing because of the breadth of his thoughts and insights in various scholarship especially Islamic religious knowledge. Noted already more than 400 titles of books that he had written either using the language of Sundanese or Indonesian/Malay. The works of the book cover various areas of Islamic disciplines such as aqid / theology, fiqih, tasawwuf akhlaq, Arabic grammar, even politics, Islamic economics. As for KHAS religious thought. Ahmad Sanusi revealed that the importance of deepening and learning about the nature, syariat and toriqot for all Muslims, especially those who will explore the world of tasawwuf.
\end{abstract}

Keywords: Islamic thought, Tasawwuf, KH. Ahmad Sanusi.

\begin{abstract}
Abstrak : Tulisan ini menyajikan tentang karya-karya dan pemikiran ulama asal daerah Sukabumi, Jawa Barat. Yakni Kyai Haji Ahmad Sanusi (KHAS). Dengan fokus karyanya dalam bidang Tasawwuf. Selain ulama Sukabumi abad ke-18 yang cukup terkenal, beliau juga seorang pemikir sekaligus penulis yang sangat produktif dalam karya-karya keagamaan. Bahkan termasuk salah seorang tokoh yang berpengaruh dalam arsip pendaftaran orang Indonesia Jang Terkemoeka jang ada di Djawa pada tahun 1942. Penelitian ini bersumber pada data-data kepustakaan. Penelitian ini menemukan, bahwa KH. Ahmad Sanusi (KHAS) salah seorang tokoh ulama produktif dalam tulis menulis karena keluasan pemikiran dan wawasannya dalam berbagai keillmuan khususnya ilmu keagamaan Islam. Tercatat sudah lebih dari 400 an judul kitab yang pernah ia tulis baik itu yang menggunakan bahasa sunda maupun Indonesia/melayu. Karya-karya kitab tersebut mencakup berbagai bidang disiplin ilmu keislaman seperti akidah/theology, fiqih, tasawwuf akhlaq, tata bahasa arab, bahkan politik, ekonomi Islam. Adapun pemikiran keagamaan KH. Ahmad Sanusi yang terungkap antara lain mengenai pentingnya mendalami dan mempelajari tentang hakikat, syariat dan toriqot bagi semua muslim khususnya yang akan mendalami dunia tasawwuf.
\end{abstract}

Kata kunci: Pemikiran Islam, Ulama, Tasawwuf, KH. Ahmad Sanusi.

\section{PENDAHULUAN}

Kata sukabumi, merupakan gabungan dari dua kata; kata "suka" yang sepadan dengan kata "senang" dan "bumi” yang sepadan degan kata 'rumah atau tempat tinggal". Sukabumi mengandung arti "senang berada di rumah". Dalam ensiklopedi berbahasa Inggris, kata Sukabumi diterjemahkan dengan kata 'paradise'. Nama Sukabumi pertama 
kali diperkenalkan ke dunia luar oleh Andries Christoffel Johannes de Wilde, seorang berkebangsaan Belanda yang menjelajah di Sukabumi guna mencari lokasi tanah yang cocok untuk perkebunan. Dalam laporan surveinya bertanggal 13 Januari 1815, De Wide mencantumkan nama Soeka Boemi (dalam dua suku kata). Dalam sejarahnya Sukabumi pernah mejadi salah satu pusat peradaban dan keislamanan di era awal abad 19. Bahkan ruang lingkupnya bukan untuk wilayah Jawa Barat saja melainkan pulau Jawa secara keseluruhan. Hal ini dibuktikan dengan ditemukannya sejumlah naskah keagamaan yang merujuk pada wilayah ini.

Kyai/Ulama yang terkenal dari Sukabumi pada saat itu ialah KH. Ahmad Sanusi (KHAS). Ia banyak menulis berbagai judul kitab, karya-karyanya menarik perhatian para pengkaji dan peneliti, sehingga ulama klasik Sukabumi menjadi indentik hanya pada KH. Ahmad Sanusi (KHAS). Beberapa alasan penulis memilih KH. Ahmad Sanusi (KHAS) sebagai objek kajian untuk diteliti, antara lain: Pertama, sebagai ulama yang hidup pada akhir abad ke-18 dan awal abad ke -19 banyak menuangkan gagasan dan pemikirannya dalam bentuk kitab atau risalah. Tidak kurang ada sekitar 400 buah judul buku tentang persoalan-persoalan agama Islam, baik itu yang menggunakan bahasa melayu maupun bahasa sunda. Bidang-bidang kelimuan dalam karya tersebut antara lain: akidah, tauhid, fiqih, tata bahasa arab, juga tasawwuf akhlaq. Kedua, dilihat dari silsilah keilmuaanya, KH. Ahmad Sanusi (KHAS) sebagai ulama besar sekaligus aktif dalam tulis menulis, sangatlah menarik untuk menelusuri pemikirannnya. Ketika belajar di Mekah, ia telah mengenal ide-ide pembaharuan Syeikh Muhammad 'Abduh, Syeikh Muhammad Rasyid Ridla, dan Jamaluddin al-Afghani, melalui buku-buku dan majalah aliran pembaharuan di Mesir, sehingga pengaruh tersebut menjadikannya ulama pembaharu ketika pulang ke Indonesia. Namun demikian, ia tetap tidak meninggalkan mahzabnya, ia tetap mengikuti mazhab Syafi'i sebagaimana yang dilakukan kedua gurunya, Syeikh Ahmad Khatib dan Syeikh Mukhtar at-Tarid. Bahkan dalam bidang ilmu fikih yang juga merupakan keahliannya, Kiai Sanusi terkenal sangat kritis terhadap dalam menentukan hukum Islam. Kajian terdahulu mengenai pemikiran KH. Ahmad Sanusi (KHAS) sesungguhnya telah banyak dilakukan Dintaranya adalah karya berjudul "Pemikiran Politik Kyai Haji Ahmad Sanusi" ditulis oleh Ade Nurpriatna. penelitaannya menyebutkan KHAS sebagai pendiri organisasi Al-Ittihadiytul Islamiyyah (AII) merupakan implementasi pemikiran teologisnya dalam menyebarkan pemikiran sosial politiknya.

Poin penting lain dijelaskan bahwa pemikiran KHAS telah mengalami metamorfosa dari teologis, pemikiran sosial pendidikan menuju pemikiran politik Islam. Kajian lain pernah dilakukan Sulasman dengan topik KH. Ahmad Sanusi (1889-1950): Berjuang dari Pesantren ke Parleman (Bandung: PW PUI Jawa Barat, 2007) penelitian menekankan aspek sejarah Kyai Sanusi sebagai tokoh ulama dan politik di konstalasi nasional. Kemudian Muhammad Iskandar dalam Kyai Haji Ajengan Ahmad Sanusi (Jakarta: PB PUI, 1993). hasil penelitian tersebut menekankan metode dakwah yang dilakukan KHAS melalui pendidikan formal pesantren dan masyarakat. Kemudian Yayan Mulyana, Metode Penafsiran Ayat-Ayat Ahkam Dalam Kitab Tamsjijatoel 
Moeslimin Karya H.Ahmad Sanusi (Tesis IAIN SGD Bandung, 2003) didalamnya menjelaskan metode-metode yang dilakukan KHAS dalam menafsirkan ayat Al-quran khususnya tentang ayat berkenaan tentang hukum-hukum. Tak kalah pentingnya Desertasi karya Wawan Hernawan dengan judul "Persatuan Ummat Islam (PUI): Latar Belakang da Perkembangannya (1911-2011). Hasilnya ditemukan beberapa fakta terbaru diantaranya; pertama, Persatuan Ummat Islam merupakan nama baru bagi dua organisasi massa Islam Madjlisoel 'Ilmi dan Al-Ittihadijatoel Islamijjah yang telah berdiri sejak masa pemerintahan Hindia Belanda; kedua, peran PUI bukan hanya dalam bidang keagamaan tetapi juga pendidikan dan sosial (ekonomi, politik). Khususnya dalam bidang politik, PUI pernah menempatkan para kadernya sebagai anggota BPUPKI, Parlemen, Konstituante, Duta Besar, Menteri, bahkan Wakil Perdana Menteri.

Karya lain berjudul "Warisan Intelektual Islam Indonesia: Telaah Atas Tafsir Malja' At-tālibin dan Tamsyiyyatul Al-muslimin Karya Haji Ahmad Sanusi (18881950) oleh Husen Hasan Basri. Dari hasil penelitian karyanya; pertama, Tafsir Malja' At-tālibin (TMT) dan Tafsir Tamsyiyyatul Al-muslimin (TTM) mempunyai kesamaan yaitu keduanya diterbitkan secara berkala yakni bulanan, yang membedakan terletak pada tahun dan tempat terbit serta isi dan sasaran konsumenya. Juga TMT bersifat tekstual sedangkan TTM agak cenderung kontektual, kedua-duanya menggunakan metode tafsir Ijmali; kedua, TMT dan TTM keduanya sebagai produk intelektual memperlihatkan adanya proses perkembangan pemikiran KHAS sebagai seorang ulama pada awal periode sejarah Indonesia modern, ia berada dan berbicara dalam kepada dua kelompok manusia yang berbeda, yaitu masyarakat yang sedang melakukan sebuah perubahan dan masyarakat yang baru mengenal dunia perubahan. Oleh karena itu, KHAS disamping seorang "modernis" ia juga seorang ulama yang menghubungkan ideide (broker of ideas). Karya lain dituliskan Fadlil Munawwar Mansur dalam Tesisnya berjudul “Ajaran Tasawwuf Dalam Raudatul-Irfani Fi Ma'-rifatil-Quran Karya Kiai Haji Ahmad Sanusi: Analisis Semiotik dan Resepsi” (Universitas Gajah Mada, Yogykarta. 1992). Kesimpulan penelitiannya mengungkap beberapa hasil diantaranya; pertama, aspek semiotik dengan menyimpulkan bahwa tradisi pesantren secara kultural merupakan salah satu sumber kelahiran karya-karya sastra keagamaan di Indonesia. Tradisi pesantren ditandai dengan lima unsur yaitu; kiai, santri, masjid, asrama, dan kitab. Kitab Raudatul-Irfani Fi Ma'-rifatil-Quran (RI) dicipta dilingkungan pesantren hasil interaksi antar unsur pesantren itu merupakan produk lingkungan sosio-budaya sunda.

Jadi kelahiran RI bermula dari tradisi pesantren yang religious, kemudian muncul RI sebagai sintesa dari proses dialektis antara kegiatan keagamaan dengan kegiatan kemasyarakatan dan kebudayaan; kedua, pandangan tasawwuf KHAS terpengaruh konsep-konsep tasawwuf Ahlussunnah Wal Jamaah (ASWJ) yang dipelopori Imam Al-Ghazali sebagai tokoh tasawwuf ortodoks. Tulisan ini difokuskan untuk melihat bagaimana pemikiran ulama lokal Sukabumi Kyai Haji Ahmad Sanusi (KHAS) dituangkan dalam berbagai bentuk kitab dan buku, terutama dalam karyanya yang belum dikaji khususnya dibidang tasawwuf. Tulisann ini diharapkan dapat 
bermanfaat secara akademis maupun praktis untuk pengembangan khazanah intelektual Islam yang diwariskan ulama asli Indonesia melalui karya-karya tulisnya.

Kerangka Konsep Sebelum memaparkan apa dan bagaimana pemikiran Kyai Haji Ahmad Sanusi (KHAS), kiranya perlu penulis definisikan terlebih dahulu istilah pemikiran keagamaan. Yang dimaksud dengan pemikiran keagamaan dalam tulisan ini ialah gagasan/ide seorang ulama atau kyai yang dituangkan dalam sebuah karya, didalamnya terkandung unsur-unsur keagamaan mulai dari aspek akidah, tauhid, fiqih, akhlaq hingga tasawwuf. Penelitian ini terfokus terhadap pemikiran yang tercermin dalam sebuah teks dari karya ulama. Teks dipandang sebagai entitas tanda yang dapat merujuk atau pesan ide-ide keislaman, sehingga teks dipandang sebagai media produksi ide atau gagasan. Tetapi ide tidak terlepas dari konteksnya, maka diperlukan pemeriksaan terhadap aspek ekternal sebuah teks. 'pemeriksaan kaitan dengan aspek ekternal teks merupakan bagian dari analisis ekternal terhadap teks (Norman Fairclough, 2014, h. 36. Analisis ekternal terhadap teks adalah mengurai bagaimana teks membingkai aksi penulis dan hubungan sosialnya, bagaimana teks membingkai representasi pandangan dunia dari realitas yang dihadapi penulis dan pembaca, juga bagaimana teks membingkai identilfikasi personal penulis dan pembaca. Pada bagian ini, penelitian ini dalam analisisnya juga dapat mengadopsi konsepsi sosiologi pengetahuan (jika teks diandaikan sebagai sebuah produksi pengetahuan), yang berpandangan bahwa sebuah pengetahuan (gagasan atau ide) itu dibangun atau dipengaruhi oleh eksistensi masnyarakat dan juga mempengaruhi masyarakat (Karl Manheim, 1954,h. 237).

Konsepsi teoritis sosiologi pengetahuan Mannheim antara lain, mengakui adanya relasi nilai-nilai sosial terhadap semua persepsi tentang realitas. Artinya, seseorag dipengaruhi oleh khalayaknya, atau sebaliknya yaitu khalayak itu dipengaruhi oleh seseorang (timbal balik). Teori ini pun mengatakan, bahwa tidak ada praktik penafsiran (act of coming-to-understanding) yang dapat terhindar dari kekuatan formatif latarbelakang (background) dan komunitas paradigma yang dianut oleh seorang penulis/pengarang (author) dan pembaca sekaligus. Konsep teks seperti ini tidak hanya dapat digunakan untuk memeriksa latar belakang sebuah teks muncul, tetapi juga dapat digunakan untuk kontektualitas teks tersebut.

\section{METODOLOGI PENELITIAN}

Penelitian ini menggunakan pendekatan sejarah sosial dan filologi. Pendekatan sejarah sosial digunakan untuk membahas biografi ulamanya, sedangkan pendekatan filologi digunakan untuk membahas kitab karya ulama. Adapun teknik pengumpulan data penelitian ini dilakukan dengan telaah pustaka atau dokumentasi. Data penelitian diperoleh dari sumber data tertulis dan dilakukan dengan dua cara yaitu; pembacaan analitis dan pencatatan. Kegiatan pembacaan analitis adalah kegiatan membaca menyeluruh dan membaca lengkap seluruh teks bacaan. Tujuan utama pembacaan analitis adalah untuk memperoleh pemahaman yang lebih dalam terhadap hal-hal yang tertulis dalam buku. Dalam hal ini, membaca analitis dilakukan untuk menemukan pemahaman dan pemikiran dalam teks dengan melakukan pengkodean (coding) ciri- 
ciri/unsur-unsur Islam moderat tersebut. Selanjutnya melakukan pencatatan data-data verbal berupa naskah-naskah karya KHAS yang berkaitan dengan fokus penelitian. Data-data verbal ini, selanjutnya ditulis kembali dalam pemaparan hasil penelitian sebagai pembuktian atas temuan-temuan. Adapun pengolahan data terhadap sumbersumber eksternal teks adalah sebagai berikut: jika sumber tersebut juga adalah sumber tertulis, maka yang dilakukan sama dengan sumber dat tertulis diatas, namun jika data berupa hasil wawancara maka yang dilakukan adalah melakukan transkripsi data wawancara terhadap murid, dan keturunan KHAS kemudian dicatat hal-hal penting melalui teknik pengkodean hal-hal yang terkait dengan fokus penelitian.

\section{HASIL PENELITIAN DAN PEMBAHASAN}

Biografi Singkat Kyai Haji Ahmad Sanusi Haji ahmad sanusi, pada masa kecilnya lebih akrab dipanggil dengan si Uci. Dilahirkan di desa Cantayan, Cibadak, Sukabumi pada 3 Muharram 1306 H (18 September 1888). Ayahnya, Haji Abdurrahim merupakan pemimpin pesantren Cantayan. Ia menyuruhnya belajar diluar pesantren yang dipimpin ayahnya tersebut. Yakni ke pesantren-pesantren yang berada di wilayah Priangan. Selama lebih kurang enam tahun belajar dari satu pesantren ke pesantren lainnya, pada tahun 1909 Ahmad Sanusi berangkat ke Mekkah untuk menjalankan ibadah haji dan memperdalam ilmu agama di sana. Di mekkah ia berguru kepada Syaikh Ali Maliki, Syaikh Ali Thayyibi, Syaikh Junaidi (asal Garut), Haji Mukhtar, Haji Abdullah Jawami, Syaikh Saleh Bafadil dan Said Jawani seorang mufti bermadzab Syafei, dan ia juga pernah berguru kepada Kyai Mahfudz Termas. Dari beberapa ulama di Mekkah tersebut, Kyai Mahfuzd merupakan ulama termashur dan berpengaruh besar bagi orang nusantara untuk generasi berikutnya.

Muhammad Ali bin Husain al-Maliki yang lebih dikenal dengan sebutan Syaikh Ali maliki juga adalah guru Kyai Haji Ahmad Sanusi yang menulis kitab 'anaarat adDuja. berawal dari perjumpaannya dengan Haji Abdul Muluk di tahun 1913, maka saat itu pula Haji Ahmad Sanusi mengenal Serikat Islam (SI). Diduga pada tahun yang sama ia mulai aktif dalam dunia tulis menulis. Saat itu tersebar surat kaleng yang menyudutkan SI, maka untuk menanggapi desas desus kejelekan SI, ia menulis buku berjudul "Nahratoe Darham". Dan itulah judul buku pertama yang ia tulis ketika berada di Mekkah yang kemudian buku tersebut dikirim kepada KH. Muhammad Bisri di Cicurug. Pada bulan Juli 1915 Haji Ahmad Sanusi kembali ke Indonesia (kurang lebih enam tahun bermukim di mekkah) untuk membantu ayahnya di pesantren Cantayan. Metode mengajar yang ia terapkan dipesantren ayahnya berbeda dengan kyai-kyai lainnya, materinya mudah diterima santri dan jemaahnnya. Maka tak heran dalam kurun waktu kurang dari empat tahun sejak kepulangannya dari Mekkah, nama Ahmad Sanusi dengan cepat dikenal masyarakat hingga mendapat julukan Ajengan Cantayan. Pada tahun 1921 atas arahan ayahnya, Ia mendirikan pesantren di kampong Genteng Babakan Sirna, Distrik Cibadak Afdeeling Sukabumi. Maka sejak saat itu ia mendapat julukan tambahan yaitu sebagai Ajengan Genteng. Di Sukabumi, tepatnya 14 syawwal 1354/5 Februari 1935 Ahmad Sanusi mulai mendirikan pesantren di Gunung Puyuh. Dinamakan Gunung Puyuh, karena di daerah itu terdapat sebuah gunung (bukit kecil) yang banyak 
dihuni burung puyuh. Sekarang gunung itu terletak di sebelah barat kompleks perguruan Syamsul 'Ulum (Miftahul Falah, 2009, h.114). kuat dugaan, itulah sebabnya pemerintah Staadgemeente Sukabumi memberi nama jalan yang melintasi daerah itu Vogelweg (jalan burung).

Pada awal pendiriannya, di pesantren Gunung Puyuh hanya ada masjid dan sebuah bangunan sederhana. Namun demikian, sama seperti pesantren Cantayan dan Genteng, pesantren Gunung Puyuh pun banyak diminati para murid. Bahkan karena banyaknya antusias para penimba ilmu satu itu banyak rumah-rumah penduduk saat itu yang dijadikan pondok untuk menampung seluruh murid-muridnya. Kyai Haji Ahmad Sanusi (KHAS) sangat produktif menuangkan gagasan pemikirannya dalam bentuk kitab atau risalah yang mencakup berbagai bidang. Sebagai seorang ulama produktif dalam dunia tulis menulis, tercatat kurang lebih ratusan karya telah beliau tulis dalam berbagai disiplin ilmu kegamaan Islam. Seperti bidang Tauhid atau ilmu kalam (teologi), Fikih (Islamic Laws), Tasawwuf (Mistisisme Islam), Tafsir (Qur'an Interpretation) dan sebagainya. Karya-karya diatas tersebut baik itu tulisannya yang bersifat elementer (berupa ajaran Islam). Ataupun yang sifatnya polemis atau diskursus intelektual. Maka atas dasar tersebut tidak lah salah kalau Martin Van Brunessen menggolongkan Haji Ahmad Sanusi ke dalam para pengarang kitab yang terkenal di zamanya tersebut (Martin Van Bruinessen, 1999, h.145). Bahkan karya-karya KHAS masih banyak tercecer dan bahkan belum dipublikasikan karena masih terdapat di tangan-tangan masyarakat umum dan dijadikan sebagai referensi permanen. Menurut penuturan keluarga dan kerabat KHAS masih banyak karangan lainnya yang belum dicatat dan dalam bentuk manuskrif (tulisan tangan) hingga jumlah keseluruhannya diperkirakan hampir mendekati angka sekitar 400-an judul kitab.

Deskripsi dan Tinjauan Singkat Karya-karya KH. Ahmad Sanusi Dalam proses pengumpulan data, penulis dalam hal ini hanya akan mengekplorasi dan meneliti karya KH. Ahmad Sanusi dalam bidang tasawwuf saja. Dan cukup banyak kitab karangan yang berkaitan dengan tasawwuf/akhlaq yang pernah ia tulis, namun disini hanya akan diungkap beberapa saja yang disinyalir muatan pemikirannya lebih menonjol dan lebih banyak tentang pemahaman dan ide gagasannya dengan tema yang sedang dibahas. Diantara kitab tersebut adalah: Siraj al-Adzkiya fi Tarjamah al-Azkiya. Berikiut ini deskripsi dan tinjauan mengenai kitab tersebut. Kitab dengan judul menggunakan bahasa arab “ سر اج الأذكياء فى ترجمة الأزكياء" Siraj al-Adzkiya fi Tarjamah al-Azkiya (artinya: lampu kebahagiaan bagi orang-orang pintar dalam menejemahkan kitab al-Azkiya). Di cover halaman awalnya tidak dicantumkan tahun terbit, hanya tertera nama tempat saja yaitu Gunung Puyuh, Sukabumi. Jumlah halaman kitab tersebut sebanyak 63+1 halaman judul. Kitab tersebut ditulis dengan bait-bait syair berbahasa arab dari setiap halamannya, dan dipinggirnya terdapat penjelasan dengan tulisan arab berbahasa sunda yang menjelaskan pokok-pokok isi kandungan syair tersebut. Lalu dibawah bait-bait syair dimuat masing-masing arti per kalimat/kata dalam bahasa sunda dengan menggunakan huruf arab. Kitab Siraj al-Adzkiya fi Tarjamah al-Azkiya terdiri dari matan (syair-syair berbahasa arab), terjemah matan dan syarah. Dalam hal ini matan 
adalah teks-teks syair kitab Siraj al-Adzkiya fi Tarjamah al-Azkiya, jadi teks-teks yang berupa syair-syair dalam kitab Siraj al-Adzkiya fi Tarjamah al-Azkiya disebut dengan matan teks. Yang wujudnya secara lengkap dapat dilihat pada syarah yang menyertainya disetiap halaman kitab tersebut (Louis Ma'luf,1956, h,. 746). Matan teks inilah yang dikupas oleh syarah, fungsi syarah adalah menguraikan, mengulas, dan menjelaskna matan teks. Syarah yang dimaksudkan dalam pembicaraan ini adalah syarah yang menguraikan, mengulas, menjelaskan, dan menafsirkan matan teks tersebut. Jadi, syarah dalam kontek ini selanjutnya dinamakan syarah teks (Dawam Raharjo, 1985, h.55). Adanya bait syair yang ditulis dengan bahasa dan huruf arab menunjukkan bahwa Kyai Haji Ahmad Sanusi (KHAS) bukan hanya seorang ulama penulis saja bahkan bisa digolongkan sebagai ulama penyair dengan gaya sastra tertentu pada masa itu. Adapun isi dari kitab tersebut antara lain membahas syariat, thariqot, dan hakikat tidak boleh dipisahkan satu sama lainnya.

1) Syariat diibaratkan dengan sebuah kapal, thariqoh bagaikan laut dan hakikat seperti inten berlian. Maka barang siapa yang ingin mengagapi posisi hakikat maka ia harus mengambil syariat dan thariqot. Wajib bagi seseorag untuk menghiasi dhahir dengan syariat supaya hati bercahaya, bersinar, nan teguh dalam menjalankan thariqoh. Tiap-tiap guru (mursyid) mempunyai thariqoh tertentu yang digunakan untuk wushul kepada Allah SWT. Seseorang yang bermaksud menjalani thariqoh wali, maka ia harus memegang teguh 9 (Sembilan) wasiat. Yaitu: 1. Taubat Rukun taubat ada empat, yaitu: 1) Menyesali atas semua perbuatan dosa. Yang dimaksud adalah tidak akan kembali lagi mengulangi perbuatan dosa tersebut, dan membersihkan diri dari hak orang lain dan tobat itu harus selamnya dengan selalu memeriksa anggota badan (jati diri sendri). Tobat merupakan pembuka (pintu) segala bentuk ketaatan, dasar segala bentuk kebaikan. Lalu apabila seseorang terjatuh dalam perbuatan dosa maka harus sesegera mungkin untuk bertaubat.

2) Qonaah Yang dimaksud dengan qonaah disini adalah meninggalkan segala bentuk keinginan nafsu dan menjauhi serta mengabaikan segala bentuk urusan yang tidak ada faidahnya.

3) Zuhud Yaitu menahan diri dari urusan duniawi, dengan cara agar hati tidak terikat dengan urusan dunia, dan bukan berarti membuang hal-hal duniawi. Zuhud merupakan posisi tertinggi setelah taqwa, dengan zuhud ini dapat menjadi perantara untuk mencapai martabat para wali yang agung. Orang yang cinta dunia bagaikan orang mabuk yang tidak jelas arah tujuan dan fikirannya. Perempuan-perempuan yang tidak saling menolong dalam ketaatan maka harus dibuang. Untuk mencapai keselamatan di dunia maka ada empat hal, yaitu; selalu bersikap pemaaf, tidak berbuat jahat, tidak mengharap belas kasihan orang lain, dan dermawan kepada sesama.

4) Mempelajari Ilmu Syariah Maka wajib memperdalam dan mempelajari ilmu syariah, yaitu 3 bidang keilmuan yang sifatnya fardu ain, diantaranya; pertama, Ilmu Fiqih. Yaitu ilmu yang mengesahkan urusan ketaatan, kedua, Ilmu Tauhid. 
Yaitu ilmu yang menangani masalah keyakinan (akidah) dan ketiga, Ilmu Tasawwuf yaitu ilmu untuk membersihkan hati.

5) Menjaga Sunnah Yang dimaksud adalah harus menjalankan segala bentuk sunnah dan adab (etika) juga ahklaq-ahklaq baik dan mulia yang datangnya dari nabi. Ilmu tasawwu semuanya adalah adab (akhlaq) karena tidak ada jalan untuk sampai kepada Allah kecuali dengan menjalankan dan menuruti Rasulullah baik dalam bentuk tingkah laku, pekerjaan dan ucapan. Maka dari itu wajib menuruti dan menelusuri segala bentuk pekerjaan dan ucapan Rasulullah SAW. Thariqoh guru-guru yang benar adalah berdasarkan Al-quran dan Hadis, maka terlebih dahulu menjalankan segala bentuk fardu atau wajib karena hal itu merupakan yang utama, lalu setelah itu menjalankan segala bentuk sunnah karena dengan menjalankan segala bentuk sunnah dapat menjadi pelantara untuk mendapatkan naungan dan diterima Allah SWT.

6) Tawakkal Bagi orang yang tidak punya tanggungan untuk diberi nafkah maka bentuk tawakalnya adalah ibadah kepada Allah SWT. Tetapi bagi yang punya keluarga yang mesti diberi nafkah, maka ia harus kasab (usaha) tetapi harus berserah diri dan percaya bahwa rizki itu dari Allah dan jangan berpagku tangan dengan mengharap pemberian oran lain.

7) Ikhlas Yaitu menjalankan segala bentuk ibadah hanya demi untuk dan karena mengharap ridha Allah SWT, tidak boleh dibarengi sifat duniawi atau karena ingin dipuji orang lain. Dan harus takut terhadap sikap riya karena menghapus pahala ibadah tersebut. Riya disini adalah beramal karena tujuan mahluq dan termasuk syirik khofi, lalu jangan memperlihatkan keunggulan karena ingin dipuji dan tidak boleh memperlihatkan kelemahan supaya terhinakan. Keimanan tidak akan sempurna bila sudah hilang rasa dan keiinginan untuk dipuji, dan takut atas cemoohan. Dan apabila seseorang ingin mendapat kemuliaan maka jangan ada harapan mendapat martabat (kedudukan) dari Allah SWT.

8) Uzlah Yang dimaksud uzlah disini adalah tidak boleh bercampur baur atau bergaul dengan orang yang senantiasa menyia-nyiakan agama dan bersikap angkuh, karena hal itu bagian dari kecelakaan yang amat besar. Ketika takut akan terkena fitnah dalam urusan agama, atau terjerumus dalam hal yang haram atau subhat maka saat kondisi seperti itu lebih baik uzlah (mengasingkan diri). Tetapi apabila bercampur baur dan bergaul dengan orang lain dalam hal ibadah atau mencari ilmu dan dalam segala bentuk yang berfaedah maka saat kondisi seperti ini lebih baik tidak beruzlah. Disamping itu pula bagi orang yang mampu dalam amar ma'ruf nahyi munkar, sabar dalam menjaga dari segala bentuk maksiat maka pada saat seperti ini haram untuk melakukan uzlah.

9) Menjaga Waktu Yang dimaksud adalah menjaga semua waktu untuk selalu dipakai ibadah, jangan sampai ada pengangguran, hal yang mubah harus menjadi ibadah dengan niat baik. Waktu harus dibagi-bagi dan pantas untuk dijadikan segala bentuk ibadah. Ketika matahari sudah terbit maka secepatnya shalat dengan khusu', dan mengingat bahwa segala perbuatan yang dhahir maupun 
batin selalu dilihat Allah. Memahami pemikiran ajaran tasawwuf dalam kitab Siraj al-Adzkiya fi Tarjamah al-Azkiya sudah bisa ditemukan pada halaman awal kitab tersebut. Ia menjelaskan dengan poin-poin diantaranya pemaparan devinisi istilah-istilah dalam tasawwuf, yaitu uraian istilah taqwa, syariat, thariqoh, dan hakikat.

Lalu menegaskan bahwa keterkaitan yang kuat antara syariat, thariqoh dan hakikat dan tidak dapat dipisahkan satu sama lainnya. Disamping itu pula Kyai Haji Ahmad Sanusi (KHAS) menguraikan ketiga unsur dalam tasawwuf itu dengan metode perumapamaan sebagai berikut: syariat dijelaskan dengan perumpamaan bagaikan sebuah kapal (perahu), thariqoh dengan perumpamaan bagaikan laut, dan hakikat bagaikan perhiasan intan berlian. Di halaman ke-2 sampai 20 dijelaskan bahwa seorang salik mesti berpegang terhadap 9 wasiat. Yaitu: taubat, qonaah, zuhud, mempelajari ilmu syariah, menjalankan sunnah., tawakkal, ikhlas, uzlah, dan menjaga waktu. Disisi lain dijelaskan berbagai bentuk fadilah/keutamaan ibadah diantaranya; keutamaan shalat berjamaah, membaca al-Quran, wirid dan tasbih. Namun juga dipaparkan berbagai tujuan dari ibadah tersebut agar seseorang dapat mencapi hakikat dari ibadahnya itu. Pada halaman berikutnya ditekankan bahwa pentingnya muthalaah (membaca) Kitab Ihya Ulumuddin karya Imam Ghazali, dan dikatakan bahwa kitab tersebut merupakan obat yang paling manjur. Lalu di halaman 55 terdapat tazkirah (peringatan) berkaitan dengan kedisiplinan ibadah dan perlu adanya vareasi dalam ibadah. Hal ini dibuktikan dalam bunyi syarah teks di halaman tersebut: "Ieu hiji peringetan: jalma anu henteu boga gawe ulah ngaledu kudu digawe ibadah, shalat. Alamun geus bosen solat pindah maca qur'an, pindah kana zdikir atawa kana tasbih. Lamun geus bosen make suara pindah kana dzikir tafakur ku hate. Ulah loba ngalamun atawa cacarita hate karena eta matak teuas hate. (Siraj al-Adzkiya fi Tarjamah al-Azkiya. Hal. 55) Syarah di atas menekankan pentingnya menjaga dan memanfaatkan waktu untuk ibadah, jangan sampai ada waktu yang disia-siakan. lalu penting juga adanya vareasi dalam ibadah supaya tidak jenuh (bosan), Hal ini diperlukan dalam menjalankan ibadah perlu juga adanya metode/cara supaya selalu dalam kondisi yang tidak membosankan dan berpindah-pindah dari cara yang satu ke cara lainnya.

Dihalaman berikutnya ia menulis Muhimmah sebagai berikut: "Ieu hiji kaperluan: geus ijma sakabeh aulia ari pang utama-utamana ibadah eta ngaraksa nafas, yaeta kaluar kajerona kudu bareng jeung zdikir "Allah-allah" atawa "Laailaha illa Allah" kalawan bedas sarta make gedag badan atawa zdikir sir henteu make gedag biwir" Penuturan di atas bisa difahami bahwa Kyai Haji Ahmad Sanusi (KHAS) telah mempertegas pendapat para ulama tasawwuf sebelumnya, dalam hal ini ia meresepsi bahwa salah satu hal utama dalam dalam tasawwuf adalah menjaga nafas dengan tidak mengosongkan nafas tersebut dengan lafadz jalalah (selalu menyebut asma Allah SWT). Kemudian dihalaman akhir kitab ditulis dalam syarahnya sebagai berikut: "Saha-saha anu henteu ngajar dirina ti mimiti kana mujahadah jeung ibadah, tangtu moal meunang bagian tini thariqoh auliya jeung tina ma'rifat khosoh. Ari mujahadah eta ngaberesihkeun nafsu tina anu hina jeung ngadangdanan nafsu ku sifat kautamaan. 
Ulama arifin leuwih utama tibatan ahli faqih jeung ahli ushul anu henteu arifin. (Siraj al-Adzkiya fi Tarjamah al-Azkiya. Hal. 59).

\section{SIMPULAN}

Berdasarkan uraian di atas dapat disimpulkan, bahwa Kyai Haji Ahmad Sanusi (KHAS) merupakan seorang kyai/ulama yang amat luas ilmunya. Keluasan ilmunya itu dibuktikan dalam keaktifannya dalam dunia tulis menulis. Hingga tercatat lebih dari 400-an judul kitab ia tulis semasa hidupnya. Judul-judul kitab yang ia tulis mencakup berbagai disiplin ilmu keislaman. Diantaranya: akidah, fiqih, tafsir, nahwu sorof dan tentunya tasawwuf. Adapun pemikiran keagamaan Kyai Haji Ahmad Sanusi (KHAS) dalam bidang tasawwuf yang terungkap antara lain: mengenai penting dan perlunya menjaga keseimbangan antara hakikat, syariat dan tariqot bagi seorang salik yang memperdalam tasawwuf. Pola pemikiran tasawwuf yang dipegang Kyai Haji Ahmad Sanusi (KHAS) adalah bermadzhab Ahlu Sunnah Waljamaah (Aswaja).

Pandangan pemikiran tasawwufnya pun terpengaruh kuat oleh konsep-konsep tasawwuf imam Al-Gazali sebagai tokoh tasawwuf ortodoks. Ortodoksi pandangan tasawwuf al-Gazali diresepsi dan diinterpretasi oleh Kyai Haji Ahmad Sanusi (KHAS) dalam terjemah matan dan syarah teks kitab Siraj al-Adzkiya fi Tarjamah al-Azkiya. Maka dengan demikian, dapat dikatakan bahwa Kyai Haji Ahmad Sanusi (KHAS) adalah salah satu ulama sekaligus pemikir yang menganut mazhab tasawwuf ortodoks. Hal ini diperkuat dalam salah satu isi kitab tersebut dinyatakan pentingnya menelaah kitab Ihya Ulumuddin Karya Imam Al-Gazali itu.

Adapun klasifikasi pemikiran tasawwuf Kyai Haji Ahmad Sanusi (KHAS) dalam kitab Siraj al-Adzkiya fi Tarjamah al-Azkiya adalah Tasawuf akhlaqi. Yaitu ajaran tasawuf yang mempelajari kesempurnaan dan kesucian jiwa melalui proses pengaturan sikap mental dan pendisiplinan tingkah laku secara ketat. Untuk mencapai kebahagiaan yang optimal, seseorang harus mengidentifikasi eksistensi dirinya dengan ciri-ciri ketuhanan (takhalluq bi akhlaqul karimah), melalui pensucian jiwa raga yang bermula dari pembentukan pribadi yang bermoral paripurna, dan berakhlaqul karimah melalui pola pensifatan sifat-sifat Allah. Disamping itu pula ditemukan klasifikasi tasawwuf 'amaly yang ditandai dengan pembahasannya mengenai thariqoh. Ini dibuktikan bahwa dalam uraian isi kitab Siraj al-Adzkiya fi Tarjamah al-Azkiya Siraj al-Adzkiya fi Tarjamah al-Azkiya terdapat Sembilan sifat (wasiat) yang perlu dimiliki bagi seorang salik dalam thariqoh. Maka dari itu dalam tradisi dan dunia tasawwuf terdapat fase-fase pendidikan jiwa dan seni menata hati yakni; takhalli, tahalli dan tajalli. Dan semua hal-hal tersebut diatas terdapat dalam isi kandungan kitab Siraj al-Adzkiya fi Tarjamah al-Azkiya karya Kyai Haji Ahmad Sanusi (KHAS) itu.

\section{DAFTAR PUSTAKA}

Ali, Muhammad bin Hussainn al-Makki al-Maliki, Anaarat ad-Duja, t,t, Syirkah Annur Asiya. Arsip Nasioanal Repulik Indonesia, 2013, Citra Kota Kukabumi Dalam Arsip". Jakarta: anri. 
Azra, Azyumardi, 1999, Ulama Jawi di Haramain: pasang dan surutnya sebuah wacana Religious-intelktual, Bandung: PT. Remaja Rosdakarya.

Bruinessen, Martin Van. 1999, Kitab Kuning: Buku-Buku Berhuruf Arab Yang Dipakai Di Lingkungan Pesantren, Bandung: Mizan.

Falah, Miftahul, 2009, Riwayat Perjuangan KH.Ahmad Sanusi, Bandung: MSI Jabar Fairclough, Norman. 2014, Analyzing Discourse: tektual analysis for social research. New York: Routledge.

Gunseikanbu, 1986, Orang Indonesia yang terkemuka di Jawa, Jogjakarta: Gadjah Mada University Press. Iskandar, Mohamad, 1993, Kyai Haji Ajengan Ahmad Sanusi: Kyai tradisional Jawa Barat, Bandung: Prisma

Ma'luf, Louis, 1956, al -Munjid fi-Lugati wal-adabi wal-'ulum, Beirut: al-Matba'atulKasulikiyyah.

Mawardi, A. Mukhtar. 1985. Haji Ahmad Sanusi: riwayat hidup dan perjuangannya, , Jakarta: IAIN Syarif Hidayatullah.

Manheim, Karl, 1954, Ideology and Utopia: an introduction to sociology of knowledge. New York dan London: Routledge dan Kegan Paul LTD.

Raharjo, Dawam, 1985, Perrgulatan Dunia Pesatren Membangun Dari Bawah, Jakarta: P3M.

Shaleh, Munandi. 2016. KH. Ahmad Sanusi, Pemikiran dan Perjuanganya Dalam Pergolakan Nasional, Tangarang: Jelajah Nusa. Sukabumi, dalam Microsoft ${ }^{\circledR}$ Encarta. 